\title{
Techno-Economic Feasibility of Biogas Plants in Pakistan
}

\author{
Muhammad Irfan Fareed ${ }^{1 *}$, M Anees Ur Rehman ${ }^{2}$, Shahmir Ahmad ${ }^{1}$ and Iqra Ghaffar ${ }^{3}$ \\ ${ }^{1}$ School of life Sciences, Unicersity of Science and Technology of China, China \\ ${ }^{2}$ Centre for Energy Systems (CES); National University of Sciences and Technology (NUST) H-12, Islamabad, Pakistan \\ ${ }^{3}$ Department Sci-Tech Communication, Unicersity of Science and Technology of China, China. \\ *Corresponding Author: Muhammad Irfan Fareed, School of life Sciences, Unicersity of Science and Technology of China, China.
}

Received: July 24, 2019; Published: September 20, 2019

DOI: 10.31080/ASMI.2019.02.0377

\begin{abstract}
Major portions of population in Pakistan do not have access to natural gas for household needs. Most of this population is residing in rural areas and utilizes wood, cow dung and liquefied petroleum gas (LPG) for meeting their cooking requirements. The utilization of these fuels is uneconomical, time consuming, unhealthy and have bad impacts for decreasing social standards of life. The current study quantifies the benefits obtained by replacing wood and LPG through biogas. The research investigates the better type of digester, capacity of the digester and fuel substitution (through biogas) in terms of economic benefits. The results indicate that fixed dome digesters have better benefits than floating drum digester.While the capacity of fixed dome digester that will give shortest payback period will $6 \mathrm{~m}^{3}$ among $4 \mathrm{~m}^{3}$ and $6 \mathrm{~m}^{3}$. LPG replacement by biogas is most economical among base case fuels utilized in rural areas of Pakistan. Replacement of LPG fuel by biogas using fixed dome digester of $6 \mathrm{~m} 3$ capacity will result in most beneficial project for having internal rate of return (IRR) and payback period of around $100 \%$ and 1 year respectively.

Keywords: Fixed Dome; Floating Drum; IRR; NPV; Payback
\end{abstract}

\section{Introduction}

Pakistan is among those countries where energy crises are among major national issues. 55\% households have electricity while only $18 \%$ have gas access respectively. Per capita energy supply is very low. $68 \%$ of country's population lives in rural areas where energy related issues are critical. They are using biomass such as firewood, animal and agricultural wastes to meet their needs [1].

The majority of the rural population uses firewood and other biomass fuels for cooking and heating while kerosene is used for lighting. Biomass has always been neglected in national energy planning and energy infrastructure. The negligence of biomass in energy planning has given rise to deforestation, loss of bio-diversity and negative health [2].

Inefficient utilization of biomass has moved rural population down the energy ladder especially women. Large fraction of rural population has exposed to unclean fuel and hazardous indoor air pollution [3]. Social life has been disturbed due to hours of extra work in searching, bringing and using this fuel. Burning of solid fuel in such a large fraction is creating environmental problems [4]. Utilizing massive quantities of biomass is contributing to environmental pollution and increasing concentration of suspended particulate matter (SPM). Burning of solid fuel is one of major source for increasing SPM in environment [5]. Pakistan Environmental Protection Agency (Pak-EPA) recorded the air quality data by monitoring stations in five cities which shows high concentration of SPM. The level of SPM below 2.5 micron in these cities is shown in figure 1 [6].

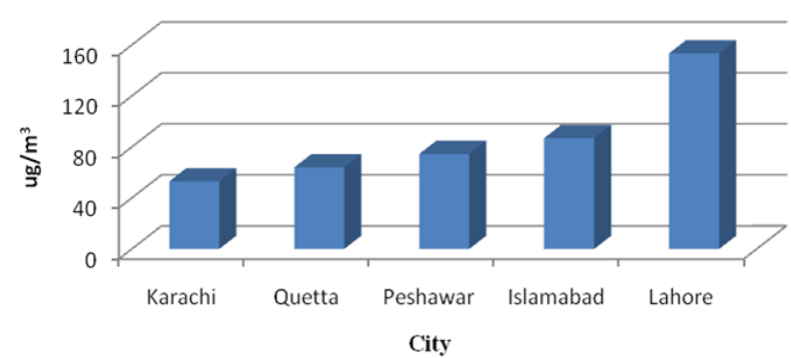

Figure 1: Annual mean value of SPM (pm 2.5) for different cities of Pakistan.

There are many semi urban areas in Pakistan which have high population density and do not have availability of natural gas distribution network. Figure 2 shows that there is an increasing gap between supply and demand for natural gas [7] which eliminates 
the possibility of natural gas availability to these semi urban areas. Towns that are not within the piped natural gas network have access to Liquefied Petroleum Gas (LPG) but high cost of this LPG makes it affordable to high income class only [8]. Large infrastructure costs for expanding natural gas distribution network, increasing demand in fertilizer sectors and critical issues to supply natural gas to vehicles on priority basis indicate that alternate options for domestic fuels must be considered for semi urban/rural areas.

Careful planning regarding biomass fuels can give economical, environmental and social benefits to major population fraction of country [9]. In rural areas, the easily available animal and agro

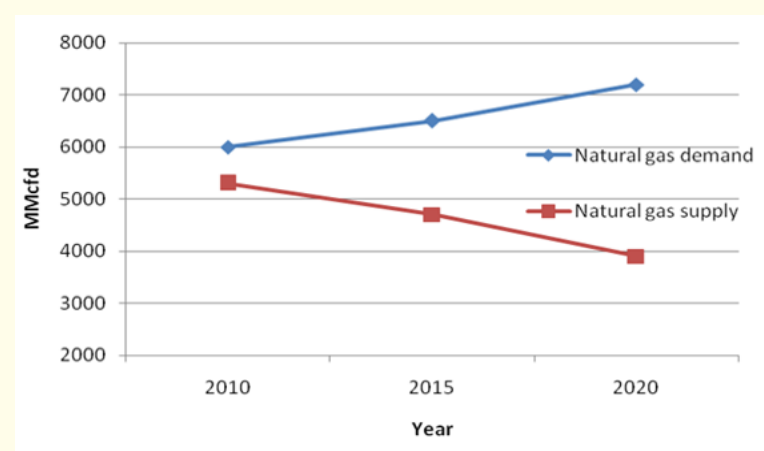

Figure 2: Demand and supply for natural gas.

based wastes can be used to generate biogas. An average household in rural area of Pakistan uses approximately 1,480 kg of dung or $2,325 \mathrm{~kg}$ of wood or $1,160 \mathrm{~kg}$ of agricultural residues per annum [10]. These resources can easily be replaced by a more efficient, economical, environmental friendly energy source, biogas. Wide scale adaptation of biogas technology among rural and semi-urban areas can help to improve economical and social setup of population residing in these areas.

Being an agricultural and livestock based economy, Pakistan has large potential of biomass energy resources [4]. Various studies were conducted previously for analyzing biogas potential in Pakistan [11]. Estimated number of cattle and buffalo is 60 to 70 million in country [12]. Other sources of biogas available abundantly are citrus pulp, paper industry, rice straw and slaughter house waste. Poultry waste is a good substrate to produce biogas and have vast availability in rural as well as sub urban areas of country. Nearly 30 million layer-chickens and 550 million broiler chickens are supplied by poultry industry every year, which shows that a lot of poultry waste is also available for biogas generation [13].
Abundant livestock and agricultural sources indicate that biogas technology could be adopted in past but Pakistan is among those agro based countries where biogas technology did not get successful penetration. Government, NGOs and private organizations had been working for implementation of biogas technology in country but due to unplanned efforts, unskilled labor and lack of awareness biogas technology did not get any significant adaptation in past. The main barriers that have hindered development of wide scale adoption of biogas are shown in figure 3 [8] with their suggested solutions and objective of current research. Government sector organizations, NGOs and private business firms working for biogas technology in Pakistan are shown in table 1 [14].

\begin{tabular}{|c|c|c|}
\hline Sr. No & Company Name & Plant Installed \\
\hline & \multicolumn{2}{|l|}{ Government Sector Organizations } \\
\hline 1 & $\begin{array}{l}\text { Pakistan Council for Appropriate } \\
\text { Technology (PCAT) }\end{array}$ & 30 \\
\hline 2 & $\begin{array}{l}\text { Directorate General of New and } \\
\text { Renewable Energy Resources (DGN- } \\
\text { RER) }\end{array}$ & 100 \\
\hline 3 & $\begin{array}{l}\text { Pakistan Centre for Renewable En- } \\
\text { ergy Technologies (PCRET) }\end{array}$ & $\sim 3600$ \\
\hline \multirow[t]{2}{*}{4} & $\begin{array}{l}\text { Pakistan Dairy development com- } \\
\text { pany (PDDC) }\end{array}$ & $\sim 550$ \\
\hline & \multicolumn{2}{|l|}{ Private SectorOrganizations (NGOs) } \\
\hline 1 & $\begin{array}{l}\text { Initiative for Rural and Sustainable } \\
\text { Development(IRSD) }\end{array}$ & 150 \\
\hline 2 & Koshish & 200 \\
\hline 3 & $\begin{array}{l}\text { Association for the development of } \\
\text { Pakistan }\end{array}$ & $\begin{array}{l}2 \text { commercial } \\
\text { projects }\end{array}$ \\
\hline 4 & $\begin{array}{l}\text { Punjab Rural Support Program( } \\
\text { PRSP) }\end{array}$ & 12 \\
\hline 5 & $\begin{array}{l}\text { Foundation for Integrated Develop- } \\
\text { ment Action (FIDA) }\end{array}$ & 3 \\
\hline 6 & $\begin{array}{l}\text { Rural Support Programme-Network } \\
\text { (RSPN) }\end{array}$ & $\begin{array}{l}\text { Projects in } \\
\text { progress }\end{array}$ \\
\hline \multirow[t]{2}{*}{7} & Green circle organization & $\begin{array}{c}\text { Community } \\
\text { based projects }\end{array}$ \\
\hline & \multicolumn{2}{|c|}{ Private Sector Organizations (Business firms) } \\
\hline 1 & Beta Pak & $\begin{array}{c}7 \text { commercial, } 27 \\
\text { domestic }\end{array}$ \\
\hline 2 & Pak-Energy solution & 3 \\
\hline 3 & Revgreen biogas & $\begin{array}{l}4 \text { commercial } \\
\text { projects }\end{array}$ \\
\hline 4 & Canadian high mark biogas company & $\begin{array}{l}\text { Projects in } \\
\text { progress }\end{array}$ \\
\hline 5 & Ravi Biogas Construction Company & $\begin{array}{l}\text { Projects in } \\
\text { progress }\end{array}$ \\
\hline 6 & $\begin{array}{l}\text { Organization of Strategy and busi- } \\
\text { ness development }\end{array}$ & $\begin{array}{l}\text { Biogas to } \\
\text { electricity }\end{array}$ \\
\hline
\end{tabular}

Table 1: Major participants in biogas market of Pakistan. 


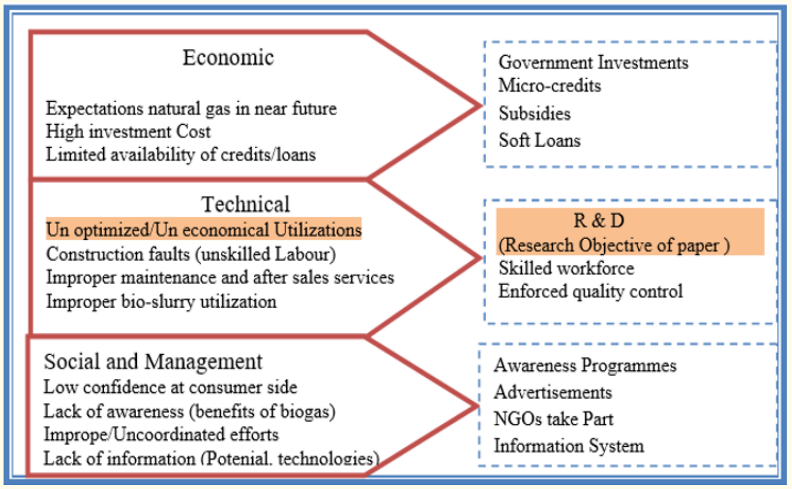

Figure 3: Barriers in Biogas Penetration in Pakistan and their Solutions.

The current research work analyzes suitable technology (digester), optimum capacity for a typical biogas digester in terms of economical parameters. Further more, it is also part of the investigation that which type of consumer's fuel should be replaced first in the initial stage of wide scale biogas penetration in the country.

\section{Materials and Methods}

Study area

In order to investigate benefits of biogas technology a typical family of 6 members is considered. As in house livestock forming for milk and meat is common practice in rural/semi urban area of Pakistan so rural/semi urban location is considered [12]. Cattle manure was considered as feed material for biogas production. Consideration of biogas plant was made for replacing base case fuels such as wood and LPG as these fuels are primary source for cooking in rural/semi urban areas. Cost data is taken from Pakistan Council of Renewable Energy Technologies (PCRET) and Netherland development organization (SNV) as these two organizations are sole market actor in biogas technology surveys and management of biogas programs in Pakistan [8]. Research method utilized is Multi criteria analysis (MCA) in which several possible options are compare for defined output variables. In current research for biogas technology, possible input options are digester type, capacity and fuel to be replaced. Output variables on the basis of which input options evaluated are economic indicators for project feasibility (NPV, IRR and Payback period). Economic savings were calculated on basis of wood/LPG replacement and bio slurry cost. Whole process scheme of the study is shown in figure 4.

\section{Technology selection}

Different designs of biogas digesters are being used in the world but in developing countries like Pakistan, most commonly adopted designs are: the Chinese fixed dome digester and the Indian float-

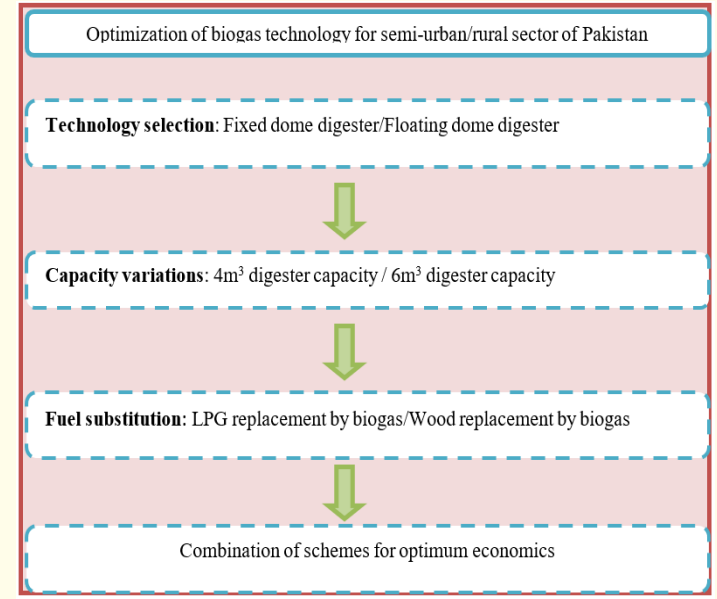

Figure 4: Process scheme of the case study for biogas technology optimization.

ing dome to handle the livestock waste for biogas production [3]. These designs are classified as low rate digesters due to their simplicity as compared to the plants in temperate regions, lacking stirring and heating capability. Floating dome digester has relatively high cost of installation and shorter lifespan [15].

\begin{tabular}{|l|c|c|}
\hline \multicolumn{1}{|c|}{ Parameter } & \multicolumn{2}{c|}{ Description/Value } \\
\hline Digester type & Fixed dome & Floating drum \\
\hline Capital cost & 50,070 & 72,570 \\
\hline Inflation rate & \multicolumn{2}{|c|}{$8 \%$} \\
\hline Fuel cost escalation rate & Wood & LPG \\
\cline { 2 - 3 } & $8 \%$ & $10 \%$ \\
\hline Location & \multicolumn{2}{|c|}{ Lahore } \\
\hline Project life & \multicolumn{2}{|c|}{ 20 years } \\
\hline
\end{tabular}

Table 2: Design and economic parameters.

The estimation of capital cost for the construction of biogas digester was made by considering the cost of raw material and technical services available in the Pakistan and it came to be $\sim 8000$ $\mathrm{PKR} / \mathrm{m} 3$ on an average. Typical design and economics related parameters are shown in Table 2. Econmic indicators for evaluation of a project are NPV, IRR and Payback period [16]. Net present value (NPV) is sum of present values of cash flows and is used to analyze the profitability of a project. As it recognizes the time value of money so it's a valuable indicator. Projects having higher NPV are attractive [17].

$N P V=\sum_{t=0}^{n} \frac{C F_{t}}{(1+r)^{t}}(1)$

Where

$r$ is the discount rate (\%) 
CFt is the cash flow in time period

$\mathrm{t}$ is the time period

IRR is economic rate of return that makes NPV zero which means that the present value of the investment funds equals the net present revenues from operation. The IRR is defined as

$\mathrm{o}=\sum_{t=0}^{n} \frac{C F_{t}}{(1+I R R)^{t}}(2)$

Where

IRR is the internal rate of return (\%)

CFt is the cash flow of the investment in time period $t$.

The advantages of IRR include that, unlike NPV, its percentage results allow projects of different sizes to be easily compared [17]. Payback period is time length for recovery of initial investment. A financially attractive project has higher NPV and IRR values while lower Payback period [18].

\section{Capacity variance}

Capacity of biogas digesters depends on daily feed material quantity, quality, hydraulic retention time and digestion temperature [19]. Commonly utilized domestic digesters sizes in Pakistan are $4 \mathrm{~m}^{3}, 6 \mathrm{~m}^{3}, 8 \mathrm{~m}^{3}$ and $10 \mathrm{~m}^{3}$. So digesters with digestion volume of $4 \mathrm{~m}^{3}, 6 \mathrm{~m}^{3}$ were chosen for typical family considered for analysis.

\section{Fuel substitutions}

In rural areas of Pakistan, wood and LPG are used for cooking and heating purposes. LPG is used in population sector which is financially sound. So these two fuels were considered for replacement with biogas.

\section{Results and Discussions}

Economic analysis results for better technology selection in table 3 and figure 5 reveals that results are quite attractive for fixed dome digester to be considered for implementation of project. NPV and IRR values are quite high while payback period is low. Fixed dome digester gives better economics because there is less capital investment. In case of Floating drum digester, steel drum needs to be replaced in lifespan of digester which makes capital investment high.

Capacity variations study of selected digester (fixed dome digester) in table 4 and figure 6 show the comparison of these capacities in terms of NPV and IRR. Results indicate that economic parameters are better with increasing capacity of digester. Figure 6 shows that payback period of $6 \mathrm{~m}^{3}$ size biogas digester is lower than $4 \mathrm{~m}^{3}$ size digester which is good to be considered. Results for better fuel replacement are shown in table 5 and figure 7 which

\begin{tabular}{|l|c|c|}
\hline Parameters & Fixed dome digester & Floating drum digester \\
\hline NPV (PKR) & $6,741,893$ & $2,630,167$ \\
\hline IRR (\%) & 50 & 35 \\
\hline
\end{tabular}

Table 3: Economic outputs of technology variation.

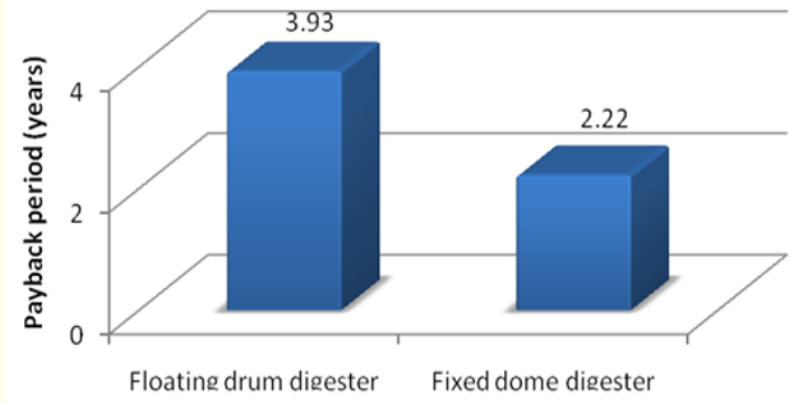

Figure 5: Payback periods for fixed dome and floating drum digesters.

depict that replacement of LPG by biogas will be more feasible in initial satges of biogas penetrations. So this combination of better technology (fixed dome digester), capacity $\left(6 \mathrm{~m}^{3}\right)$ and fuel replacement makes the economics of the project highly attractive to be considered.

\begin{tabular}{|l|c|c|}
\hline \multicolumn{1}{|c|}{ Parameters } & Fixed dome $\mathbf{( 4 m}^{\mathbf{3}} \mathbf{)}$ & Fixed dome $\mathbf{( 6 m}^{\mathbf{3}} \mathbf{)}$ \\
\hline Capital cost (PKR) & 42344 & 50070 \\
\hline NPV (PKR) & $3,487,435$ & $6,763,993$ \\
\hline IRR (\%) & 35 & 50 \\
\hline
\end{tabular}

Table 4: Economic outputs of capacity variation.

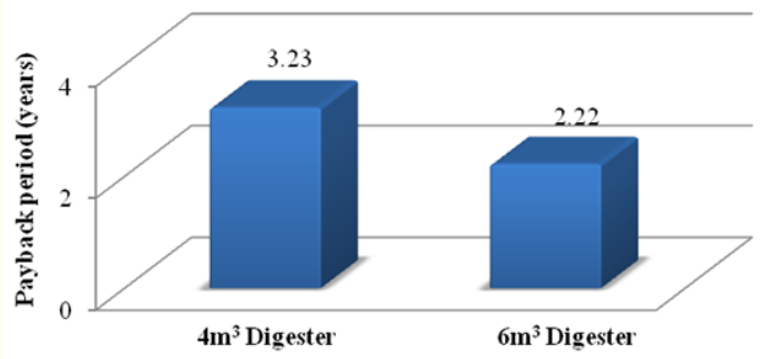

Figure 6: Payback periods for $4 \mathrm{~m}^{3}$ and $6 \mathrm{~m}^{3}$ digesters. 


\begin{tabular}{|l|c|c|}
\hline Parameters & Wood vs. Biogas & LPG vs. Biogas \\
\hline NPV (PKR) & $6,763,993$ & $18,914,475$ \\
\hline IRR (\%) & 50 & 102 \\
\hline
\end{tabular}

Table 5: Economic outputs of fuel substitutions.

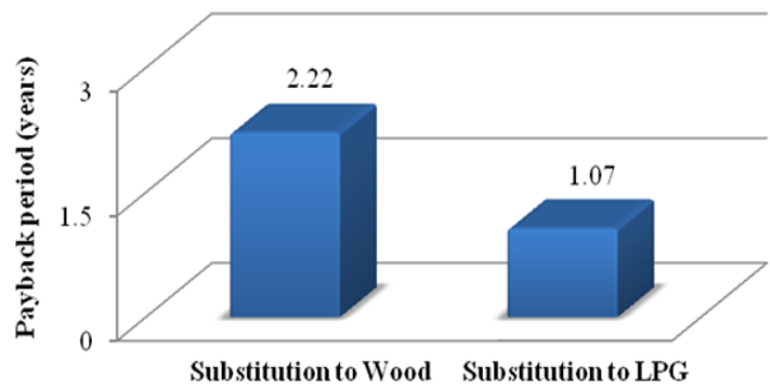

Figure 7: Payback periods for substitutions of wood and LPG by biogas.

Sensitivity study of input economic parameters to output economic indicators (NPV, IRR) is an essential element for competitive feasibility study of a project. In further economic optimization of proposed project, sensitivity of payback period to initial cost and fuel cost (LPG) is shown in figure 8, 9. Results reveal that payback period decreases with decrease in initial investment and increase in fuel cost (LPG). So both these uncertainties are better for project economics.

Current research finds feasible biogas installation options and then connect them to develop a economically optimized biogas installation model to be considered for implementation in present natural gas shortage scenario of Pakistan.

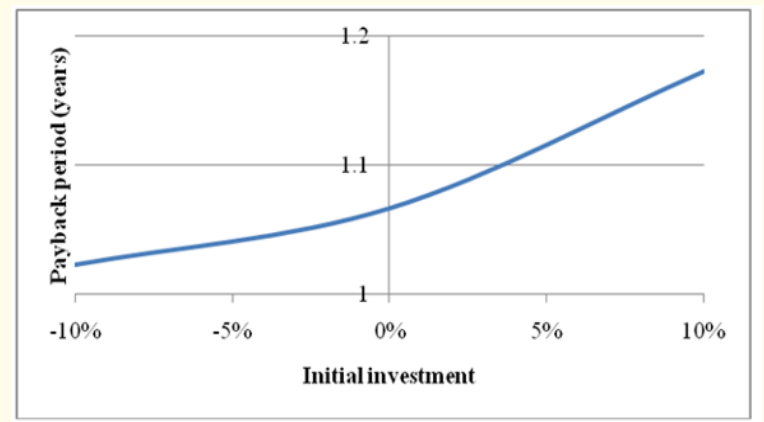

Figure 8: Sensitivity of Payback period to initial investment.

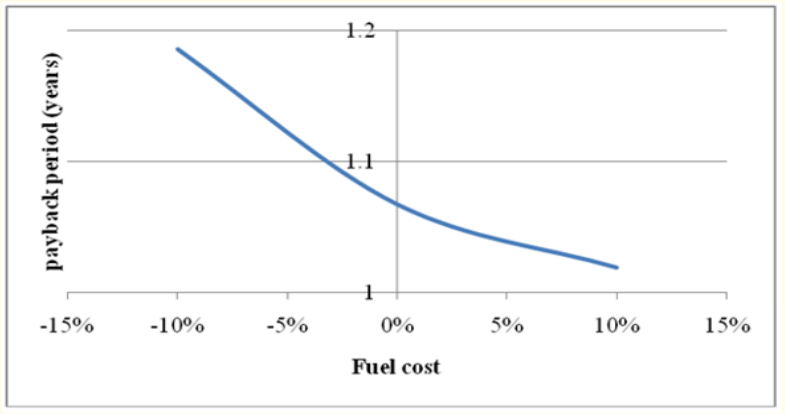

Figure 9: Sensitivity of Payback period to fuel cost.

\section{Conclusion}

The current research is carried out for investigating economical benefits obtained by replacing conventional fuels utilized in rural areas of Pakistan through biogas. The economical benefits are obtained in terms of NPV, IRR and Payback period for different scenarios considered. It was found that fixed dome digester gives higher IRR and NPV than floating drum digesters. Analysis was done in order to find better capacity which indicates that $6 \mathrm{~m} 3$ will result in better project economics among $4 \mathrm{~m}^{3}$ and $6 \mathrm{~m}^{3}$ capacities of fixed dome digesters. In fuel substitution analysis it was found that by replacement of LPG higher IRR and NPV can be obtained. Combination of all these scenarios, $6 \mathrm{~m} 3$ fixed dome biogas digester for replacing LPG makes economics of project highly attractive to be considered in ongoing promotional projects of biogas technology in Pakistan.

\section{Bibliography}

1. Harijan K., et al. "Renewable energy for managing energy crisis in Pakistan". Wireless Networks, Information Processing and Systems, Springer (2008): 449-455.

2. Fatmi Z., et al. "Situational analysis of household energy and biomass use and associated health burden of indoor air pollution and mitigation efforts in Pakistan". International Journal of Environmental Research and Public Health 7.7 (2010): 29402952.

3. Rajendran K., et al. "Household biogas digesters-A review". Energies 5 (2012): 2911-2942.

4. Tahir S., et al. "Biomass fuel burning and its implications: deforestation and greenhouse gases emissions in Pakistan". Environmental pollution 158 (2010): 2490-2495. 
5. Pant P and R M Harrison. "Critical review of receptor modelling for particulate matter: a case study of India". Atmospheric Environment 49 (2012): 1-12.

6. Ghauri B., et al. "Development of baseline (air quality) data in Pakistan". Environmental Monitoring and Assessment 127 (2007): 237-252.

7. Malik S N and O R Sukhera. "Management of natural gas resources and search for alternative renewable energy resources: A case study of Pakistan". Renewable and Sustainable Energy Reviews 16 (2012): 1282-1290.

8. Heegde T F and B Pandey. Programme Implementation Document for a National Programme on Domestic Biogas Dissemination in Pakistan (2008).

9. Uddin W., et al. "Biogas potential for electric power generation in Pakistan: A survey". Renewable and Sustainable Energy Reviews 54 (2016): 25-33.

10. Mirza U K., et al. "An overview of biomass energy utilization in Pakistan". Renewable and Sustainable Energy Reviews 12 (2008): 1988-1996.

11. Shahzad A and S Hanif. "Techno-economic feasibility of biogas generation in Attari village, Ferozepur road, Lahore". Environment, Development and Sustainability 16 (2014): 977-993.

12. Khan M J., et al. "Current issues and future prospects of dairy sector in Pakistan". Science, Technology and Development 32 (2013): 126-139.

13. Akhtar MS., et al. "Effect of feeding powdered Nigella sativa L. seeds on poultry egg production and their suitability for human consumption". Veterinarski arhiv 73.3 (2003): 181-190.

14. Ghimire P C. “Final Report on Technical Study of Biogas Plants Installed in Pakistan" (2007).

15. Gunnerson C G., et al. "Anaerobic digestion: Principles and practices for biogas systems" (1986).

16. Bishop C P and C R Shumway. "The economics of dairy anaerobic digestion with coproduct marketing". Review of Agricultural Economics 31.3 (2009): 394-410.

17. Karellas S., et al. "Development of an investment decision tool for biogas production from agricultural waste". Renewable and Sustainable Energy Reviews 14.4 (2010): 1273-1282.
18. Weingartner HM. "Some new views on the payback period and capital budgeting decisions". Management Science 15.12 (1969): B-594-B-607.

19. Viswanath P., et al. "Anaerobic digestion of fruit and vegetable processing wastes for biogas production". Bioresource Technology 40.1 (1992): 43-48.

\section{Volume 2 Issue 10 October 2019}

(c) All rights are reserved by Muhammad Irfan Fareed., et al. 